\title{
Desulfosoma caldarium gen. nov., sp. nov., a thermophilic sulfate-reducing bacterium from a terrestrial hot spring
}

Correspondence

Sandra Baena

baena@javeriana.edu.co

\author{
Sandra Baena, ${ }^{1}$ Natalia Perdomo, ${ }^{1}$ Catalina Carvajal, ${ }^{1}$ Carolina Díaz $^{1}$ \\ and Bharat K. C. Patel ${ }^{2}$ \\ ${ }^{1}$ Unidad de Saneamiento y Biotecnología Ambiental, Departamento de Biología, Pontificia \\ Universidad Javeriana, POB 56710, Bogotá, Colombia \\ ${ }^{2}$ Microbial Gene Research and Resources Facility, School of Biomolecular and Physical Sciences, \\ Griffith University, Brisbane, Queensland 4111, Australia
}

\begin{abstract}
A thermophilic, sulfate-reducing bacterium, designated strain USBA- $053^{\top}$, was isolated from a terrestrial hot spring located at a height of $2500 \mathrm{~m}$ in the Colombian Andes $\left(5^{\circ} 45^{\prime} 33.29^{\prime \prime} \mathrm{N}\right.$ $73^{\circ} 6^{\prime} 49.89^{\prime \prime}$ W), Colombia. Cells of strain USBA- $053^{\top}$ were oval- to rod-shaped, Gramnegative and motile by means of a single polar flagellum. The strain grew autotrophically with $\mathrm{H}_{2}$ as the electron donor and heterotrophically on formate, propionate, butyrate, valerate, isovalerate, lactate, pyruvate, ethanol, glycerol, serine and hexadecanoic acid in the presence of sulfate as the terminal electron acceptor. The main end products from lactate degradation, in the presence of sulfate, were acetate, $\mathrm{CO}_{2}$ and $\mathrm{H}_{2} \mathrm{~S}$. Strain USBA- $053^{\top}$ fermented pyruvate in the absence of sulfate and grew optimally at $57{ }^{\circ} \mathrm{C}$ (growth temperature ranged from $50{ }^{\circ} \mathrm{C}$ to $62{ }^{\circ} \mathrm{C}$ ) and $\mathrm{pH} 6.8$ (growth $\mathrm{pH}$ ranged from 5.7 to 7.7 ). The novel strain was slightly halophilic and grew in $\mathrm{NaCl}$ concentrations ranging from 5 to $30 \mathrm{~g} \mathrm{I}^{-1}$, with an optimum at $25 \mathrm{~g} \mathrm{I}^{-1} \mathrm{NaCl}$. Sulfate, thiosulfate and sulfite were used as electron acceptors, but not elemental sulfur, nitrate or nitrite. The $\mathrm{G}+\mathrm{C}$ content of the genomic DNA was $56 \pm 1 \mathrm{~mol} \%$. 16S rRNA gene sequence analysis indicated that strain USBA-053 ${ }^{\top}$ was a member of the class Deltaproteobacteria, with Desulfacinum hydrothermale MT- $96^{\top}$ as the closest relative (93\% gene sequence similarity). On the basis of physiological characteristics and phylogenetic analysis, it is suggested that strain USBA- $053^{\top}$ represents a new genus and novel species for which the name Desulfosoma caldarium gen. nov., sp. nov. is proposed. The type strain of the type species is USBA-053 ${ }^{\top}$ $\left(=\right.$ KCTC $5670^{\top}=$ DSM $\left.22027^{\top}\right)$.
\end{abstract}

Colombian Andean hot springs provide multiple habitats and micro niches (Thevenieau et al., 2007), which can potentially be inhabited by highly metabolically diverse micro-organisms. Several of these springs associated with volcanic activity have been recorded at elevations of up to $2500 \mathrm{~m}$ in the Colombian central Andes, comprising the Western, Central and Eastern mountain ranges, located in the tropical zone, with their climate determined by their high altitude. The springs have different physical and geochemical characteristics with temperatures ranging from $20{ }^{\circ} \mathrm{C}$ to $75{ }^{\circ} \mathrm{C}$, salinity from 0.4 to $55 \mathrm{~g} \mathrm{l}^{-1}$ and $\mathrm{pH}$ from 3.7 to 7.2 . Sulfate, chloride and bicarbonate (in decreasing order) are the dominant anions (Alfaro, 2002). As sulfate is the dominant ion in these Andean hot springs,

Abbreviation: BM, basal medium.

The GenBank/EMBL/DDBJ accession number for the $16 \mathrm{~S}$ rRNA gene sequence of strain USBA $53^{\top}$ is FJ491989. and sulfate-reducing micro-organisms play a key role in the degradation of organic matter in many anoxic ecosystems, our research group has focussed its attention on studies of thermophilic sulfate-reducing microbes from these hot springs. Thermophilic sulfate-reducing bacteria are currently classified into several families including the Thermodesulfobacteriaceae, Desulfohalobiaceae, Desulfomicrobiaceae, Syntrophobacteraceae, Peptococcaceae and Thermodesulfobiaceae (Rogosa, 1971; Hatchikian et al., 2002; Mori et al., 2003; Kuever et al., 2006a, b, c). In this report, the isolation and characterization of a novel thermophilic sulfate-reducing member of the family Syntrophobacteraceae is described.

Sediment and water samples were collected from three hot springs (identified as sites P3, P4 and P6) located in the Andean region at $5^{\circ} 45^{\prime} 33.29^{\prime \prime} \mathrm{N} \quad 73^{\circ} 6^{\prime} 49.89^{\prime \prime} \mathrm{W}$, $5^{\circ} 45^{\prime} 30.69^{\prime \prime} \mathrm{N} \quad 73^{\circ} 6^{\prime} 50.61^{\prime \prime} \mathrm{W}$ and $5^{\circ} 43^{\prime} 37.29^{\prime \prime} \mathrm{N}$ $73^{\circ} 7^{\prime} 9.19^{\prime \prime} \mathrm{W}$, respectively. Samples were collected in 
sterile glass containers that were filled to the brim, capped and transported to the laboratory. The temperatures at the sampling points ranged between $53{ }^{\circ} \mathrm{C}$ and $68{ }^{\circ} \mathrm{C}$, the $\mathrm{pH}$ was 7.0 and the conductivity ranged from 43 to $52 \mathrm{mS} \mathrm{cm}{ }^{-1}$. The sulfate concentration varied between 8750 (P6) and $19250 \mathrm{mg} \mathrm{l}^{-1}$ (P3 and P4) and the total dissolved solids varied between $39 \mathrm{~g} \mathrm{l}^{-1}$ (P3 and P4) and $41.8 \mathrm{~g} \mathrm{l}^{-1}$ (P6). The sodium content was $12.5 \mathrm{~g} \mathrm{l}^{-1}$ for sites $\mathrm{P} 3$ and $\mathrm{P} 4$ and $5.5 \mathrm{~g} \mathrm{l}^{-1}$ for site $\mathrm{P} 6$.

Enrichments were initiated by inoculating $1 \mathrm{ml}$ samples from each of the three springs into Hungate tubes containing $5 \mathrm{ml}$ pre-reduced anaerobic basal medium (BM) supplemented with sodium lactate $(20 \mathrm{mM})$, anhydrous sodium sulfate $(20 \mathrm{mM}), 1$ g yeast extract $\mathrm{l}^{-1}$ and $3 \mathrm{~g}$ $\mathrm{MgCl}_{2} \mathrm{l}^{-1}$. BM contained $\left(1^{-1}\right.$ deionized water): $0.3 \mathrm{~g}$ $\mathrm{KH}_{2} \mathrm{PO}_{4} ; 0.3 \mathrm{~g} \mathrm{~K}_{2} \mathrm{HPO}_{4} ; 1.0 \mathrm{~g} \mathrm{NH}_{4} \mathrm{Cl} ; 23 \mathrm{~g} \mathrm{NaCl} ; 0.1 \mathrm{~g}$ $\mathrm{KCl} ; 3.0 \mathrm{~g} \quad \mathrm{MgCl}_{2} .6 \mathrm{H}_{2} \mathrm{O} ; 0.1 \mathrm{~g} \quad \mathrm{CaCl}_{2} .2 \mathrm{H}_{2} \mathrm{O} ; 0.5 \mathrm{~g}$ cysteine-HCl; $10 \mathrm{ml}$ trace mineral element solution (Balch et al., 1979) and $1 \mathrm{ml}$ stock solution of resazurin $\left(1 \mathrm{~g} \mathrm{l}^{-1}\right)$. The headspace gas for cultivation was $\mathrm{N}_{2} / \mathrm{CO}_{2}$ $(80: 20)$. Prior to use, $0.05 \mathrm{ml} \mathrm{Na}_{2} \mathrm{~S} .9 \mathrm{H}_{2} \mathrm{O}\left(20 \mathrm{~g} \mathrm{l}^{-1}\right)$ and $0.1 \mathrm{ml} \mathrm{NaHCO} 3\left(100 \mathrm{~g} \mathrm{l}^{-1}\right)$ were injected into each tube. Increasing turbidity and $\mathrm{H}_{2} \mathrm{~S}$ production from sulfate reduction were observed in enrichments from all three samples after 6 days incubation at $55{ }^{\circ} \mathrm{C}$. Microscopic examination revealed the presence of oval- to short rodshaped cells which were present singly or in pairs. After repeated transfers, stable cultures with the same dominant cellular morphology and sulfide production were obtained from all enrichment cultures. The enrichments at this point were diluted serially and inoculated into growth medium amended with $20 \mathrm{~g} \mathrm{l}^{-1}$ Noble agar (Sigma) using the rolltube technique (Hungate, 1969). After 5 days incubation, white to brown circular convex colonies developed in the roll-tubes. Single well-isolated colonies were transferred into the growth medium and the procedure repeated at least twice before the cultures were regarded as pure. Purity was verified by inoculating the cultures in basal medium containing $1 \mathrm{~g}$ yeast extract $1^{-1}$ and $20 \mathrm{mM}$ glucose. An absence of growth in this glucose-containing medium was used as an indicator of culture purity. Five morphologically similar cultures were isolated on basal medium containing lactate and sulfate. All strains were found to stain Gramnegative and were motile, anaerobic, thermophilic, nonspore-forming and reduced sulfate to sulfide. 16S rRNA genes of the isolates were sequenced and showed $100 \%$ similarity to each other. Consequently, only one isolate, designated strain USBA- $053^{\mathrm{T}}$ from the P3 hot spring, was selected for further characterization.

Morphology was determined by phase-contrast microscopy (Eclipse 50; Nikon) and electron microscopy as described by Patel et al. (1985). Cells of strain USBA- $053^{\mathrm{T}}$ stained Gramnegative, were oval- to rod-shaped $(1.0-1.5 \mu \mathrm{m} \times 2.0 \mu \mathrm{m})$, often occurred in pairs and were motile by means of a single polar flagellum (Fig. 1). Oval-shaped cells were frequently observed in the exponential growth phase, whereas late cultures exhibited slighter longer rod-shaped cells. Spores were not observed under light or electron microscopy. In addition, cultures incubated at $80{ }^{\circ} \mathrm{C}$ for up to $20 \mathrm{~min}$ followed by subculturing into fresh growth medium failed to grow, suggesting the absence of heat-resistant bodies such as spores.

Characterization studies were performed in BM supplemented with $20 \mathrm{mM}$ sodium lactate, $20 \mathrm{mM}$ anhydrous sodium sulfate, $1 \mathrm{~g}$ yeast extract $\mathrm{l}^{-1}$ and $3 \mathrm{~g} \mathrm{MgCl}_{2} \mathrm{l}^{-1}$. Cell growth was monitored photometrically at $580 \mathrm{~nm}$ and all tests were performed in triplicate with the strain subcultured at least once under the same experimental conditions before use. The $\mathrm{pH}$ of the basal medium was adjusted to between 4.0 and 9.0 with stock solutions of $\mathrm{NaHCO}_{3}\left(100 \mathrm{~g} \mathrm{l}^{-1}\right)$ and $\mathrm{Na}_{2} \mathrm{CO}_{3}\left(100 \mathrm{~g} \mathrm{l}^{-1}\right)$. Strain USBA $-053^{\mathrm{T}}$ grew optimally at $\mathrm{pH} 6.8$ (growth $\mathrm{pH}$ range between $\mathrm{pH} 5.7$ and 7.7). The optimum temperature for growth was $57{ }^{\circ} \mathrm{C}$ (growth temperature range, $50-62{ }^{\circ} \mathrm{C}$ ) and the sodium chloride optimum was $25 \mathrm{~g} \mathrm{l}^{-1}$ (growth range was $5-30 \mathrm{~g} \mathrm{NaCl}^{-1}$ ). Unless indicated otherwise, all subsequent growth experiments were conducted using these optimal conditions.

Utilization of organic carbon sources was tested in basal medium containing $1 \mathrm{~g}$ yeast extract $\mathrm{l}^{-1}$. Strain USBA- $053^{\mathrm{T}}$ grew heterotrophically on formate, propionate, butyrate, valerate, isovalerate, lactate, pyruvate, ethanol, glycerol, serine and hexadecanoic acid at $10 \mathrm{mM}$ using sulfate as the

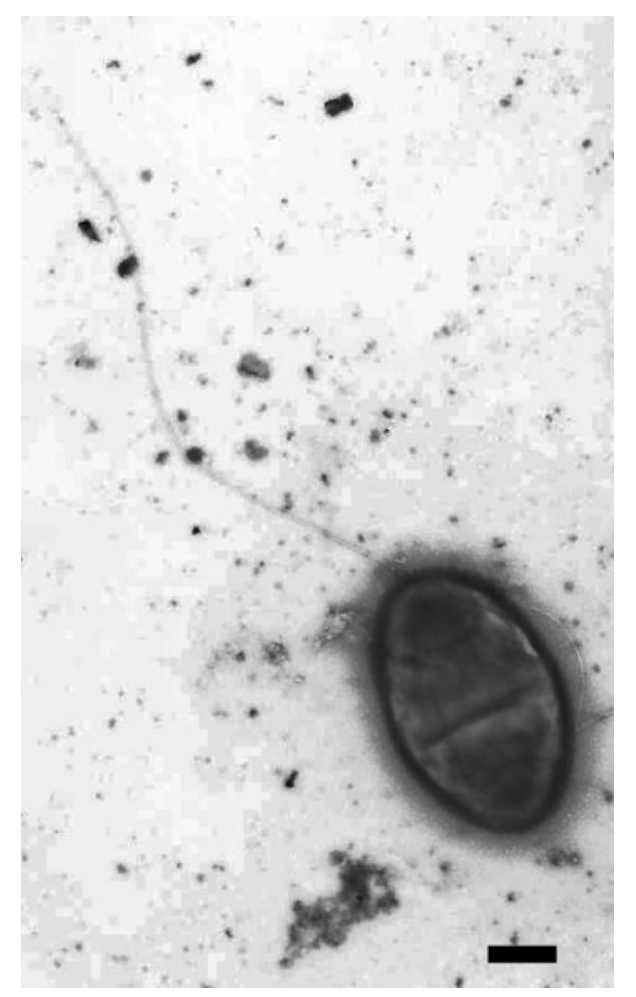

Fig. 1. Transmission electron micrograph of a negatively stained cell of strain USBA- $053^{\top}$ showing a polar flagellum. Bar, $0.5 \mu \mathrm{m}$. 
terminal electron acceptor. The isolate did not require peptides or vitamins for growth although $0.25 \mathrm{~g}$ yeast extract $\mathrm{l}^{-1}$ and $0.5 \mathrm{~g}$ Bio-Trypticase $\mathrm{l}^{-1}$ (Sigma) enhanced growth. To examine the utilization of potential electron acceptors, thiosulfate, sulfate and nitrate at $20 \mathrm{mM}$, sulfite at $2 \mathrm{mM}$ and elemental sulfur at $10 \mathrm{~g} \mathrm{l}^{-1}$ were used in BM containing $20 \mathrm{mM}$ lactate, formate or pyruvate. Sulfide production was determined photometrically using the method of CordRuwisch (1985). After 2 weeks of incubation at $55{ }^{\circ} \mathrm{C}$, end products were measured by HPLC (Shimadzu) equipped with a reversed-phase Ultra Aqueous C18 column (Restek; $150 \mathrm{~mm} \times 4.6 \mathrm{~mm} \mathrm{ID)}$ ), with a diode array detector (SPDM20A, Shimadzu) at $210 \mathrm{~nm}$. The main end products resulting from lactate were acetate $(6.0 \mathrm{mM}), \mathrm{CO}_{2}$ and $\mathrm{H}_{2} \mathrm{~S}$ in the presence of sulfate. Fermentation of $10 \mathrm{mM}$ lactate, pyruvate, serine or $1 \mathrm{~g}$ yeast extract $\mathrm{l}^{-1}$ was tested in BM, but strain USBA- $053^{\mathrm{T}}$ fermented only pyruvate to acetate. Growth was not observed on glucose, galactose, sucrose, acetate, fumarate, succinate, malate, citrate, ethanol, methanol, pepticase or Casamino acids, in the presence or absence of sulfate. Sulfate, thiosulfate and sulfite were utilized as electron acceptors, but not elemental sulfur, ferric iron or nitrate. Autotrophic growth was determined using BM supplemented with sodium sulfate at $20 \mathrm{mM}$ and $\mathrm{H}_{2} / \mathrm{CO}_{2}$ $(80: 20, \mathrm{v} / \mathrm{v})$ at a 2 bar atmosphere and strain USBA- $053^{\mathrm{T}}$ grew autotrophically under these conditions. Sensitivity to chloramphenicol and penicillin $\mathrm{G}$ was determined at a final concentration of 50 and $100 \mu \mathrm{g} \mathrm{ml}^{-1}$, respectively. Strain USBA- $053^{\mathrm{T}}$ was inhibited by $50 \mu \mathrm{g}$ chloramphenicol ml $\mathrm{m}^{-1}$ and $100 \mu \mathrm{g}$ penicillin $\mathrm{G} \mathrm{ml} \mathrm{m}^{-1}$ at $57^{\circ} \mathrm{C}$.

The DNA of strain USBA- $053^{\mathrm{T}}$ was prepared by using the whole genome amplification method (Ogg \& Patel, 2009). The $\mathrm{G}+\mathrm{C}$ content of this amplified DNA was determined by the thermal denaturation $\left(T_{\mathrm{m}}\right)$ method (Marmur \& Doty, 1962) and calculated to be $56 \pm 1 \mathrm{~mol} \%$.
The methods for 16S rRNA gene amplification and sequencing have been reported previously (Andrews \& Patel, 1996). Sequences generated were assembled into a single contig and the consensus sequence of $1479 \mathrm{nt}$ was corrected manually for errors using BioEdit v5.0.1 (Hall, 1999). The most closely related sequences in the GenBank (version 152) and the Ribosomal Database Project II (release 10) identified using BLAST (Altschul et al., 1997) were extracted, aligned and manually adjusted according to the $16 \mathrm{~S}$ rRNA secondary structure using BioEdit. Nucleotide ambiguities were omitted and evolutionary distances calculated using the Jukes and Cantor option (Jukes \& Cantor, 1969) in TREECON (Van de Peer et al., 1997). Phylogenetic trees were reconstructed from evolutionary distances using the neighbour-joining method (Saitou \& Nei, 1987). Tree topology was re-examined by the bootstrap method of resampling (1000 replications) (Felsenstein, 1985).

16S rRNA gene sequence analysis (1479 bp) consistently placed strain USBA- $053^{\mathrm{T}}$ in the vicinity of the genus Desulfacinum, family Syntrophobacteraceae, class Deltaproteobacteria (Fig. 2). The closest phylogenetic relatives to the novel strain were members of the genus Desulfacinum, with Desulfacinum hydrothermale MT-96 ${ }^{\mathrm{T}}$ and Desulfacinum infernum $\mathrm{B} \alpha \mathrm{Gl}^{\mathrm{T}}$ sharing $93 \%$ gene sequence similarity. The novel strain was distantly related to Desulfoglaeba alkanexedens $\mathrm{ALDC}^{\mathrm{T}}$ and Thermodesulforhabdus norvegica A $8444^{\mathrm{T}}$ with gene sequence similarities of $92 \%$ and $89 \%$, respectively.

Strain USBA- $053^{\mathrm{T}}$ shared a number of phenotypic and physiological properties with Desulfacinum hydrothermale and Desulfacinum infernum (Table 1). All three strains were oval to short rods and were thermophilic, halophilic and sulfate-reducing bacteria that were able to reduce thiosulfate and sulfite and grow autotrophically with $\mathrm{H}_{2}$

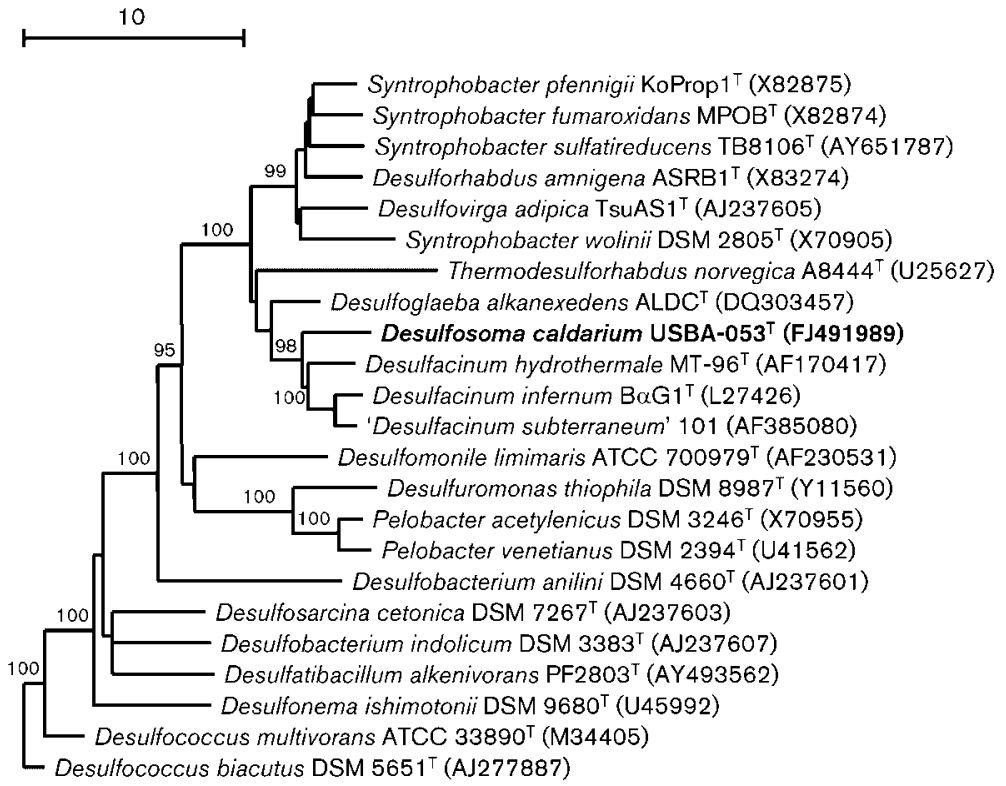

Fig. 2. Neighbour-joining phylogenetic tree, based on 16S rRNA gene sequences, showing the positions of strain USBA-053 ${ }^{\top}$ and representatives of related taxa. Bootstrap values are shown as percentages (based on 1000 replications) and only values $>95 \%$ are shown. Desulfococcus biacutus was used as an outgroup. GenBank accession numbers are given in parentheses. Bar, 10 substitutions per 100 nt positions. 
Table 1. Characteristics of Desulfacinum infernum, Desulfacinum hydrothermale and strain USBA-053 ${ }^{\top}$

Taxa: 1, strain USBA-053 ${ }^{\mathrm{T}}$ (data from this study); 2, Desulfacinum infernum $\mathrm{B} \alpha \mathrm{Gl}^{\mathrm{T}}$ (Rees et al., 1995); 3, Desulfacinum hydrothermale MT-96 (Sievert \& Kuever, 2000). All strains are able to ferment pyruvate. +, Positive; -, negative.

\begin{tabular}{|c|c|c|c|}
\hline Characteristic & 1 & 2 & 3 \\
\hline Cell width $(\mu \mathrm{m})$ & $1.0-1.5$ & 1.0 & $0.8-1.0$ \\
\hline Cell length $(\mu \mathrm{m})$ & 2.0 & $2.5-3.0$ & $1.5-2.5$ \\
\hline Optimal temperature/range $\left({ }^{\circ} \mathrm{C}\right)$ & $57(50-62)$ & $60(40-65)$ & $60(37-64)$ \\
\hline Optimal $\mathrm{NaCl}$ content/range $\left(\mathrm{g} \mathrm{l}^{-1}\right)$ & $25(5-30)$ & $10(0-50)$ & $32-36(15-78)$ \\
\hline \multicolumn{4}{|l|}{ Electron donors: } \\
\hline Alanine & - & + & + \\
\hline Fumarate & - & + & - \\
\hline Glycerol & + & + & - \\
\hline Malate & - & + & - \\
\hline Succinate & - & + & - \\
\hline Growth factor requirement & None & Vitamins & None \\
\hline
\end{tabular}

and on short chain fatty acids. In addition, they used formate, propionate, butyrate, valerate, isovalerate, ethanol, pyruvate, lactate and $\mathrm{H}_{2} / \mathrm{CO}_{2}$, but not sucrose or citrate.

However, strain USBA- $053^{\mathrm{T}}$ differed from Desulfacinum hydrothermale MT- $96^{\mathrm{T}}$ and Desulfacinum infernum $\mathrm{B} \alpha \mathrm{G} 1^{\mathrm{T}}$ in its narrow temperature range for growth and utilization pattern of electron donors; strain USBA- $053^{\mathrm{T}}$ did not oxidize acetate, succinate, malate, fumarate or alanine. Because strain USBA- $053^{\mathrm{T}}$ was both phenotypically and phylogenetically distinct from Desulfacinum hydrothermale MT- $96^{\mathrm{T}}$ and Desulfacinum infernum $\mathrm{B} \alpha \mathrm{G} 1^{\mathrm{T}}$ and the $\mathrm{G}+\mathrm{C}$ content of the genomic DNA of strain USBA- $053^{\mathrm{T}}$ also differed from these species, it is concluded that strain USBA- $053^{\mathrm{T}}$ represents a new genus and novel species for which the name Desulfosoma caldarium gen. nov., sp. nov. is proposed.

\section{Description of Desulfosoma gen. nov.}

Desulfosoma (De.sul.fo.so'ma. L. pref. de from; L. n. sulfur sulfur; N.L. pref. desulfo- prefix used to characterize a dissimilatory sulfate-reducing prokaryote; Gr. neut. n. soma body; N.L. neut. n. Desulfosoma sulfate-reducing body).

Cells are oval- to rod-shaped. Obligately anaerobic. Sulphate-reducing and thermophilic. Do not form spores. Gram-reaction is negative. The type species is Desulfosoma caldarium.

\section{Description of Desulfosoma caldarium sp. nov.}

Desulfosoma caldarium (cal.da'ri.um. L. neut adj. caldarium pertaining to warmth, warming).
Exhibits the following properties in addition to those given the genus description. Cells are $1.0-1.5 \mu \mathrm{m} \times 2.0 \mu \mathrm{m}$, often occur in pairs and are motile by means of a single polar flagellum. Growth occurs between $50{ }^{\circ} \mathrm{C}$ and $62{ }^{\circ} \mathrm{C}$ (optimum, $57^{\circ} \mathrm{C}$ ). The $\mathrm{pH}$ range for growth is $\mathrm{pH} 5.7-$ 7.7 (optimum, pH 6.8). Slightly halophilic and grows in $\mathrm{NaCl}$ concentrations ranging from 5 to $30 \mathrm{~g} \mathrm{l}^{-1}$, with an optimum of $25 \mathrm{~g} \mathrm{NaCl} \mathrm{l}^{-1}$. Sulfate, thiosulfate and sulfite are used as electron acceptors, but not elemental sulfur, nitrate or nitrite. Electron donors utilized in the presence of sulfate are formate, propionate, butyrate, valerate, isovalerate, lactate, pyruvate, ethanol, glycerol, serine and hexadecanoic acid. The main end products resulting from lactate degradation, in the presence of sulfate, are acetate, $\mathrm{CO}_{2}$ and $\mathrm{H}_{2} \mathrm{~S}$. The type strain ferments pyruvate. Grows autotrophically on hydrogen. Sensitive to chloramphenicol and penicillin.

The type strain, USBA- $053^{\mathrm{T}} \quad\left(=\right.$ KCTC $5670^{\mathrm{T}}=\mathrm{DSM}$ $22027^{\mathrm{T}}$ ), was isolated from terrestrial hot springs (Paipa, Colombia). The $\mathrm{G}+\mathrm{C}$ content of the genomic DNA of the type strain is $56 \pm 1 \mathrm{~mol} \%\left(T_{\mathrm{m}}\right)$.

\section{Acknowledgements}

This work was supported by grants from IFS (International Foundation for Science), and Instituto Colombiano para el Desarrollo de la Ciencia y la Tecnología (Colciencias).

\section{References}

Alfaro, C. (2002). Geoquímica del sistema geotérmico de Paipa, pp. 215. Bogotá, Colombia: Ingeominas.

Altschul, S. F., Madden, T. L., Schäffer, A. A., Zhang, J., Zhang, Z., Miller, W. \& Lipman, D. J. (1997). Gapped BLAST and PSI-BLAST: a new 
generation of protein database search programs. Nucleic Acids Res 25, 3389-3402.

Andrews, K. T. \& Patel, B. K. C. (1996). Fervidobacterium gondwanense sp. nov., a new thermophilic anaerobic bacterium isolated from nonvolcanically heated geothermal waters of the Great Artesian Basin of Australia. Int J Syst Bacteriol 46, 265-269.

Balch, W. E., Fox, G. E., Magrum, L. J., Woese, C. R. \& Wolfe, R. S. (1979). Methanogens: reevaluation of a unique biological group. Microbiol Rev 43, 260-296.

Cord-Ruwisch, R. (1985). A quick method for the determination of dissolved and precipitated sulfides in cultures of sulfate-reducing bacteria. J Microbiol Methods 4, 33-36.

Felsenstein, J. (1985). Confidence limits on phylogenies: an approach using the bootstrap. Evolution 39, 783-791.

Hall, T. A. (1999). BioEdit: a user-friendly biological sequence alignment editor and analysis program for Windows 95/98/NT. Nucleic Acids Symp Ser 41, 95-98.

Hatchikian, E. C., Ollivier, B. \& Garcia, J. L. (2002). Family I. Thermodesulfobacteriaceae fam. nov. In Bergey's Manual of Systematic Bacteriology (The Archaea and the deeply branching and phototrophic Bacteria), 2nd edn, vol. 1, p. 390. Edited by D. R. Boone, R. W. Castenholz \& G. M. Garrity. New York: Springer-Verlag.

Hungate, R. E. (1969). A roll tube method for cultivation of strict anaerobes. Methods Microbiol 3B, 117-132.

Jukes, T. H. \& Cantor, C. R. (1969). Evolution of protein molecules. In Mammalian Protein Metabolism, pp. 21-123. Edited by H. H. Munro. New York: Academic Press.

Kuever, J., Rainey, F. A. \& Widdel, F. (2006a). Family III. Desulfohalobiaceae fam. nov. In Bergey's Manual of Systematic Bacteriology, 2nd edn, vol. 2C, pp. 948-949. Edited by D. J. Brenner, N. R. Krieg, J. T. Staley \& G. M. Garrity. New York: Springer.

Kuever, J., Rainey, F. A. \& Widdel, F. (2006b). Family II. Desulfomicrobiaceae fam. nov. In Bergey's Manual of Systematic Bacteriology, 2nd edn, vol. 2C, p. 944 . Edited by D. J. Brenner, N. R. Krieg, J. T. Staley \& G. M. Garrity. New York: Springer.

Kuever, J., Rainey, F. A. \& Widdel, F. (2006c). Family I. Syntrophobacteraceae fam. nov. In Bergey's Manual of Systematic
Bacteriology, 2nd edn, vol. 2C, p. 1021. Edited by D. J. Brenner, N. R. Krieg, J. T. Staley \& G. M. Garrity. New York: Springer.

Marmur, J. \& Doty, P. (1962). Determination of the base composition of deoxyribonucleic acid from its thermal denaturation temperature. J Mol Biol 5, 109-118.

Mori, K., Kim, H., Kakegawa, T. \& Hanada, S. (2003). A novel lineage of sulfate-reducing microorganisms: Thermodesulfobiaceae fam. nov., Thermodesulfobium narugense, gen. nov., sp. nov., a new thermophilic isolate from a hot spring. Extremophiles 7, 283-290.

Ogg, C. D. \& Patel, B. K. C. (2009). Caloramator australicus sp. nov., a thermophilic, anaerobic bacterium from the Great Artesian Basin of Australia. Int J Syst Evol Microbiol 59, 95-101.

Patel, B. K. C., Morgan, H. W. \& Daniel, R. M. (1985). Fervidobacterium nodosum gen. nov. and spec. nov., a new chemoorganotrophic, caldoactive, anaerobic bacterium. Arch Microbiol 141, 63-69.

Rees, G. N., Grassia, G. S., Sheehy, A. J., Dwivedi, P. P. \& Patel, B. K. C. (1995). Desulfacinum infernum gen. nov., sp. nov., a thermophilic sulfate-reducing bacterium from a petroleum reservoir. Int J Syst Bacteriol 45, 85-89.

Rogosa, M. (1971). Peptococcaceae, a new family to include the Grampositive, anaerobic cocci of the genera Peptococcus, Peptostreptococcus and Ruminococcus. Int J Syst Bacteriol 21, 234-237.

Saitou, N. \& Nei, M. (1987). The neighbor-joining method: a new method for reconstructing phylogenetic trees. Mol Biol Evol 4, 406425.

Sievert, S. M. \& Kuever, J. (2000). Desulfacinum hydrothermale sp. nov., a thermophilic, sulfate-reducing bacterium from geothermally heated sediments near Milos Island (Greece). Int J Syst Evol Microbiol 50, 1239-1246.

Thevenieau, F., Fardeau, M.-L., Ollivier, B., Joulian, C. \& Baena, S. (2007). Desulfomicrobium thermophilum sp. nov., a novel thermophilic sulfate-reducing bacterium isolated from a terrestrial hot spring in Colombia. Extremophiles 11, 295-303.

Van de Peer, Y., Jansen, J., De Rijk, P. \& De Wachter, R. (1997). Database on the structure of small ribosomal subunit RNA. Nucleic Acids Res 25, 111-116. 